\title{
A second chance for failed entrepreneurs: a good idea?
}

\author{
Sandra Gottschalk • Bettina Müller
}

Accepted: 13 October 2021 / Published online: 12 February 2022

(C) The Author(s) 2021, corrected publication 2022
Plain English Summary It is often argued that failure is a particularly rich source of learning. It is reasonable to expect, therefore, that entrepreneurs who have failed once will do better the second time than those who try for the first time. In this paper, we compare the survival chances of businesses of entrepreneurs who failed with their ventures in the past with those of first-time entrepreneurs (novices). We find that entrepreneurs whose previous business has failed keep new businesses running for less time than novices do. This result remains even after a series of robustness checks in which we look at different subgroups of entrepreneurs. Thus, we cannot find evidence for the assumption that previous entrepreneurial failure is particularly valuable for entrepreneurs. To explain our result, we point to the selection process that takes place before we see failed entrepreneurs another time in business. Some of the failed entrepreneurs decide to start again, while others do not, and it is likely that this process is not random. A potential driver of this process is entrepreneurial talent and our results are consistent with the hypothesis that failed entrepreneurs are those with belowaverage entrepreneurial talent. Although this does not imply that all entrepreneurs who failed have poor talent, a general second-chance policy cannot be easily justified. A targeted search and support of highprofile entrepreneurs among the failed might be more sensible.
B. Müller $(\bowtie)$

University of Mannheim, Institute for SME Research, L9, 1-2, D-68161 Mannheim, Germany

e-mail: mueller@ifm.uni-mannheim.de 
Keywords Habitual entrepreneurship .

Entrepreneurial failure experience $\cdot$ New business survival $\cdot$ IAB/ZEW Start-up Panel

\section{JEL classifications $\quad \mathrm{L} 26 \cdot \mathrm{L} 25 \cdot \mathrm{M} 13$}

\section{Introduction}

Many new businesses fail. For example, Mata and Portugal (1994) report that only about half of the firms in their dataset survived the first 4 years and Audretsch (1991) finds that only a third of new firms are still in operation after 10 years. In general, this is not much cause for concern. As Coelho and McClure (2005) argue, if a firm does not stand the market test, i.e. generate revenues that are sufficiently higher than the costs, it is reasonable to dissolve the business because the applied resources can be used elsewhere in a more productive way. Furthermore, there is evidence that even failed firms provide a source of knowledge surviving firms can use (Hoetker \& Agarwal, 2007; Knott \& Posen, 2005; McGrath, 1999) and that with excess market entry and corresponding failure rates, surviving firms are better adapted to their environment (Knott \& Posen, 2005).

By contrast, what might be a matter of concern is what happens to the entrepreneurs who run businesses that fail. Failed entrepreneurs are experienced entrepreneurs and, according to human capital theory, experience provides a source of learning (Becker, 1967; Mincer, 1974). This suggests that failed entrepreneurs have built up activity-specific human capital that would be wasted if they withdrew from entrepreneurship. Based on this line of reasoning, many countries have established so-called "second chance" policies to help failed entrepreneurs start new businesses. For example, the European Commission sees bankruptcy as an opportunity and claims that failed entrepreneurs learn from their mistakes and perform better the second time than novice (i.e., first-time) entrepreneurs (European Commission, 2007). Therefore, the Commission took the initiative to improve insolvency laws to facilitate restart after failure in the European Union.

It is quite natural to discuss the expected outcomes of failed entrepreneurs (or more general: of habitual entrepreneurs, i.e., entrepreneurs with previous business experience irrespective of the outcome of the former business) in a human capital context. Next to formal education and on-the-job training, professional experience has been among the central ways considered to improve the knowledge, skill, and personality set of individuals since Becker (1967) and Mincer (1974) started the discussion on the importance of human capital for economic outcomes. For an entrepreneur, relevant professional experience results from running a business. Accordingly, most research analyses habitual entrepreneurship from a human capital perspective (Ucbasaran et al, 2008) and concentrates on questions such as How do entrepreneurs learn (Cope, 2003, 2005; Minniti \& Bygrave, 2001; Politis, 2005)?, or Do or can they really learn (Frankish et al, 2012; Parker, 2013; Shepherd, 2003; Ucbasaran et al, 2010)? Although this work has provided valuable insights about habitual entrepreneurship, one important issue has rarely been taken into account in previous analyses: selection. Failed entrepreneurs have gone through a process of decisions to close down the business and to restart again before we see them the next time. It is reasonable to assume that this process is not random. By contrast, a potential driver of the selection process is the entrepreneurial talent of the individuals (Chen, 2013; Eesley \& Roberts, 2012; Rocha et al, 2015). Talent may determine who fails with the first business and, accordingly, who is in the pool of potential second-time entrepreneurs. Entrepreneurial talent may then also determine who "takes heart for restart" (Metzger, 2006a). Thus, the observed outcomes of businesses of failed secondchance entrepreneurs relative to those of novice entrepreneurs are as likely to be the result of an underlying selection process as the effect of learning.

In this paper, we empirically investigate how failed entrepreneurs fare in a subsequent venture in terms of survival. We make several contributions to the entrepreneurship literature. First, we are among the first to explicitly examine the relationship between the previous failure experience of entrepreneurs and the outcome of the current venture using a large representative dataset of young firms. Although there is a long tradition of analyzing the influence of previous self-employment experience on the outcome of the current venture, only recently attempts have been made to consider whether this experience was successful or not. Regarding failure experience, the extant literature is very thin. We are aware of only four studies to explore the topic. Two are working 
papers (Metzger, 2006b, 2007); one looks only at venture-capital-backed firms (Gompers et al, 2010), and the other focuses on errors made by entrepreneurs in their restart decisions (Nielsen \& Sarasvathy, 2016), an area of interest that diverges from our own. The narrowness of the previous literature has, among other things, to do with the fact that the outcome of previous self-employment experience is not recorded in the datasets or that the data indicates only whether or not the previous venture closed down. However, it has been repeatedly acknowledged that closure is not necessarily failure (Bates, 2005; Headd, 2003; Wennberg et al, 2010). We know from our dataset whether the previous and the current firm went bankrupt or were dissolved, which are more direct measures of venture failure. ${ }^{1}$ Second, by considering selection, we aim at broadening the perspective of entrepreneurship research on self-employment experience to the processes that take place before the restart of another venture. We describe the selection process in the next section, deduce a hypothesis about the potential effect of failure experience on survival in a followup venture by applying existing theoretical models to our research question, and apply considerations on selection next to learning in the interpretation of our results. Third, while previous studies often focus on specific subgroups of entrepreneurs, such as venture capital-backed start-ups or start-ups in a specific sector, we use a large representative dataset for our empirical analyses. We are, therefore, in a position to paint a wide-ranging picture of the phenomenon.

Our paper is closely related to that of Metzger (2007), who estimates the effect of entrepreneurial experience on the survival of the current business. However, in contrast to Metzger (2007), who considers entrepreneurial experience more broadly, we concentrate on failure experience. The more focused perspective allows us to delve into detail at greater length. Furthermore, while Metzger (2007) focuses on the human capital and learning component of entrepreneurial experience, we explicitly include the possibility of selection on entrepreneurial talent. This

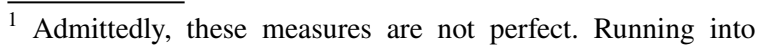
bankruptcy can simply be bad luck because, for example, a customer does not pay on time. However, bad luck is less likely an explanation when bankruptcy happens several times in a row, something which we can show with our data. We are thus quite confident that our measures are good indicators of failure.
}

has proved particularly helpful in interpreting our results. We also use a dataset with better information on the entrepreneurs and their companies. This allows us to control for more factors, estimate differentiated models and run a series of robustness checks to confirm our results.

We find that failed entrepreneurs are different from novice entrepreneurs. Thus, failed entrepreneurs are indeed not a random sample of all entrepreneurs. In addition, failed entrepreneurs have a lower likelihood of surviving with their new venture than novice entrepreneurs. Furthermore, failed entrepreneurs are not only more likely than novices to close their venture voluntarily; they are also more likely to go bankrupt. The effect of going bankrupt with a higher probability is particularly pronounced for those who went bankrupt with a previous business. This indicates that the higher closure rates of failed entrepreneurs are not exclusively due to entrepreneurs' realizing that their business idea is not viable ("intelligent failure"). The results change only marginally for a series of subgroups of entrepreneurs when we consider the number of past failure events instead of a dummy variable indicating previous failure, or if we control for entrepreneurs' inclination to pursue high-risk projects. Overall, our findings are consistent with the conjecture that negative selection takes place and, therefore, that failure in a previous venture is an indicator of poor entrepreneurial talent.

The rest of the paper proceeds as follows. We first review the theoretical arguments on learning from past entrepreneurial experience including entrepreneurial failure and on selection with a focus on what they imply for the relative performance of failed entrepreneurs and novices (Section 2). In Section 3, we describe our dataset. We present our results in Section 4 and discuss them in Section 5.

\section{Previous research}

\subsection{Learning from past entrepreneurial experience and entrepreneurial failure}

Human capital is defined to be the knowledge, skills, abilities, values, habits, and other individual characteristics that allow a person to produce economic value. According to human capital theory, individuals with higher levels of human capital have higher 
levels of productivity (Becker, 1967; Mincer, 1974). Learning is an increase in a person's human capital. This can occur in several ways, e.g., through schooling and on-the-job training but also through professional experience. Hence, it is reasonable to assume that failed entrepreneurs are better in their second venture, and better compared with novices as well, because they have experience in a relevant domain (i.e., in running a firm) and, unlike novices, thus had the chance to learn.

A series of arguments have been put forward explaining why experienced entrepreneurs can be expected to outperform novice entrepreneurs based on the concept of human capital. On a general level, authors conjecture that being self-employed is the best type of entrepreneurial training because running a business is a trial-and-error process (Brüderl et al, 1992). Furthermore, it is suggested that knowledge of "how to be entrepreneurial" (p. 6) can be gained only through learning-by-doing (Minniti \& Bygrave, 2001) and that it is learning from experience that makes an entrepreneur effective (Smilor, 1997). Experience allows entrepreneurs to build up valuable knowledge about relevant contacts, reliable suppliers, profitable markets, and availability of products and resources (Hudson \& McArthur, 1994; Ronstadt, 1988; Shepherd et al, 2000; Starr \& Bygrave, 1992) that may help them avoid the pitfalls of novices (Politis, 2005). Experienced entrepreneurs have also had the chance to develop the ability to judge whether an idea is worth pursuing, to identify and accomplish the relevant steps for setting up a firm, and to deal with uncertain situations (Baron \& Ensley, 2006; Dimov, 2010). Furthermore, experienced entrepreneurs may have developed an entrepreneurial mindset that allows them to pursue opportunities with great discipline (McGrath \& MacMillan, 2000) and to build on cognitive schemata that help connect seemingly unrelated issues (Gruber et al, 2012).

Researchers have argued that entrepreneurs not only learn from experience in general but also from failure in particular. Minniti and Bygrave (2001) describe the process of entrepreneurial learning as a calibrated algorithm of an iterated choice problem where entrepreneurs learn from both success and failure. Failure is even regarded as a unique opportunity for learning (Simor, 1997). It shows that something went wrong and that something needs to be done (Sitkin, 1992), identifies previously unknown uncertainties (McGrath, 1999; Sarasvathy, 2001; Sitkin, 1992), and induces entrepreneurs to look for new options (Politis, 2005). Crises in one form or another are also regarded as prerequisites for so-called "higher-level learning" (Cope, 2003, 2005), also known as "deep-learning" (Brown, 2000) or "generative learning" (Gibb, 1997; Senge, 1990). This occurs if people change their mental models, frames of references, and theories for action and is triggered by some unusual, non-routine event, or puzzling dilemma. Cope $(2003,2005)$ contends that entrepreneurs can experience distinctive forms of higher-level learning by facing, overcoming, and reflecting on significant incidences such as failure. This then leads to a choice of actions that differ from the previous ones, thereby increasing the action set of the entrepreneur and potentially paving the way for new actions such as innovations. Overall, from a human capital perspective, entrepreneurial experience is beneficial for entrepreneurs because it brings opportunities to learn.

Although these considerations are very valuable and insightful, one important aspect in the discussion of habitual entrepreneurship is often neglected. This is the aspect of self-selection. Ex-entrepreneurs decide whether to start again, and therefore, the group of habitual entrepreneurs cannot be assumed to be a random sample of all entrepreneurs (Chen, 2013; Lafontaine \& Shaw, 2016; Rocha et al, 2015). As a result, the driver of the selection process is likely to play an important role in the performance of habitual entrepreneurs relative to novice entrepreneurs and, if correlated with experience, is captured in the variable measuring entrepreneurial experience. Thus, neglecting this driver potentially leads to overestimating the importance of learning (Chen, 2013; Lafontaine \& Shaw, 2016; Rocha et al, 2015).

In the next section, we describe this process and apply existing arguments from the literature to the performance of failed entrepreneurs when they start another business.

\subsection{The selection process}

Figure 1 shows the selection process for entrepreneurs who fail with their first business in schematic form. At some point in time, we have a cohort of new starters (inexperienced entrepreneurs or novices) who each set up a business. After a while, some of the novices decide to sell their business or pass it on to 


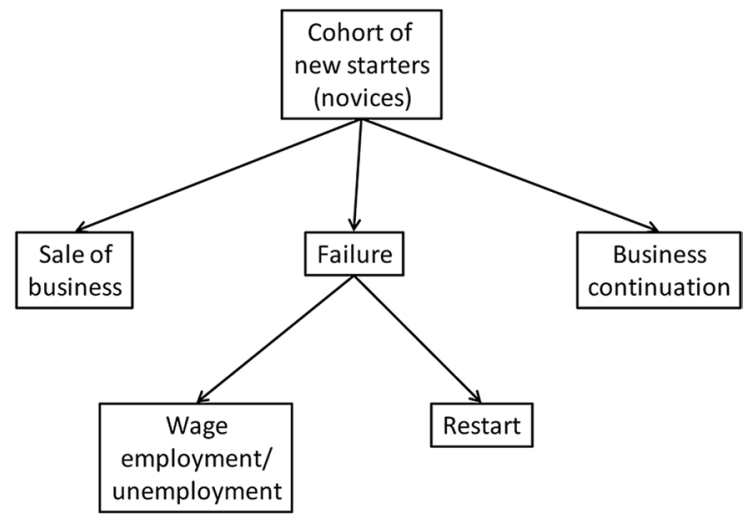

Fig. 1 The selection process for entrepreneurs who failed with their first business

a successor, some of them close the business because of failure and some of them continue with their first business. Of the failed entrepreneurs, a certain proportion decide not to return to entrepreneurship but to become wage-employed or, if they cannot find wage work, stay unemployed, while the remaining failed entrepreneurs "take heart for restart" (Metzger, 2006a, p.1). Of course, the entrepreneurs who sell their business may start up again as well. But because in this paper we are interested in failed entrepreneurs, we neglect this part of the selection process. ${ }^{2}$

The question now is: What drives this selection process? Following Chen (2013), Rocha et al. (2015), and Lafontaine and Shaw (2016), a reasonable candidate is the innate entrepreneurial ability or entrepreneurial talent of individuals. This picks up the quite old idea in industrial evolution and occupation choice models that individuals - and therefore entrepreneurs - are heterogeneous. ${ }^{3}$ In the following, we review the literature with respect to the outcome from this process. Anticipating our own data analysis, we focus on the performance of firms run by previously failed habitual entrepreneurs relative to those of novices. We first consider the relative expected ability of

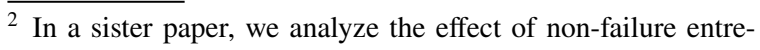
preneurial experience, i.e., restart after sale of a business and opening another business next to an already existing one (portfolio entrepreneurship (Gottschalk et al, 2017).

${ }^{3}$ Lucas (1978), for example, analyzes the implications of heterogeneous individuals that differ with respect to entrepreneurial ability for the choice between wage work and self-employment.
}

entrepreneurs who just failed (i.e., of entrepreneurs who are in the "Failure"-box in Fig. 1, Section 2.2.1), and then of entrepreneurs who failed and started another time (i.e., of entrepreneurs who reach the "Restart"-box in Fig. 1, Section 2.2.2). According to our knowledge, four theoretical papers from the previous literature are relevant. The models differ with regard to whether or not entrepreneurs know their entrepreneurial talent.

\subsubsection{From start to failure}

In his model of dynamic selection, Jovanovic (1982) assumes that individuals do not know their entrepreneurial talent but can learn about it by running a business. The members of a cohort of novices regard themselves as a random draw from the same distribution of entrepreneurial talent (here: ability to run a firm efficiently) but they do not know where they are in this distribution. In the beginning, they all start with the same expectations about their ability (the expected value of the ability distribution) and then use signals from the market to update their beliefs about their ability levels. Entrepreneurs who get feedback from the market that they are of a low-cost type (i.e., a high-ability type) expand their business and grow. Entrepreneurs who receive signals from the market suggesting that they have low ability will shrink their business and eventually fail. Thus, this model suggests that entrepreneurs who fail for the first time tend to have low entrepreneurial ability. Of course, this does not hold for every failed entrepreneur because the signals from the market include a random component, i.e., it can also happen that highability entrepreneurs decide to close their business simply because they happen to get the wrong market signal about their true ability. But on average, entrepreneurs who close down their business, i.e., fail, can be expected to have lower entrepreneurial ability than the group of novices as a whole.

By contrast, both Holmes and Schmitz (1990), Plehn-Dujowich (2010), and Carbonara et al. (2019) assume that people know their entrepreneurial talent and that it is also observable by others. In this setting, failure and success are a matter of luck. However, talent and luck are not unrelated in all three models. Holmes and Schmitz (1990) assume that individuals with higher talent are more likely to develop a business of good quality. This leads to two threshold 
levels of entrepreneurial ability: a level below which people never start businesses because the likelihood that they ever would develop a business with positive market value is too low; and a level above which people specialize in starting businesses. These highability entrepreneurs develop a business idea and, depending on the quality of the business, they either discontinue it or sell it after the development phase and then start developing another business idea. Individuals whose entrepreneurial ability lies between the threshold levels start businesses as well but may also decide to manage their previously developed business. This depends on the talent of the individual, the quality of the business, and on the transaction costs accompanying the transfer of businesses.

Regarding our question of interest, the outcome depends on the level of the transaction costs. If there are no transaction costs, there will be a level of business quality below which both low-skilled and highskilled entrepreneurs discontinue their business (i.e., fail) and above which the business is sold. As lowskilled entrepreneurs are more likely to develop a business of low quality, the average entrepreneurial talent among the entrepreneurs who fail is lower than among novices. But when allowing for transaction costs, some low-skilled entrepreneurs decide to manage their previously developed business and some high-skilled entrepreneurs decide to discontinue their business even though it has a similar quality to the one that the low-skilled entrepreneurs decide to manage. This reflects the reality that high-skilled entrepreneurs are more ambitious. In sum, if transaction costs are sufficiently high, the average ability of failed entrepreneurs could be higher than that of novice entrepreneurs.

Plehn-Dujowich (2010) assumes that the quality of the business is assigned randomly to all entrepreneurs. In his model, entrepreneurs differ to the extent that they benefit from a given idea. Entrepreneurs with higher ability run businesses with higher profits but they also benefit more from a business of high quality than entrepreneurs with a lower entrepreneurial ability (i.e., entrepreneurial talent and business quality are complementary). As in the model by Holmes and Schmitz (1990), the consequence is that individuals with low entrepreneurial talent do not choose to become entrepreneurs but employees. In the Plehn-Dujowich (2010) model, the actions of entrepreneurs depend on the randomly assigned quality of the business (i.e., on their luck) and on their entrepreneurial skills. Because capital depreciates over time and there are serial start-up costs - i.e., not all capital can be transferred between businesses - the expected return from entrepreneurship in the second round (and further rounds) must be higher than in the first round to keep the option of running a business more attractive than becoming an employee. Consequently, lucky entrepreneurs that find a business idea that is sufficiently good maintain their business in operation (forever). Unlucky high-skilled entrepreneurs who get a business idea of low quality shut down the business and open a new one. Unlucky lowskilled entrepreneurs shut down and become employees. The last case happens because business quality must compensate for missing talent. In terms of our question, this implies that the average ability of those who close their businesses is lower than that of novice entrepreneurs.

Just like Plehn-Dujowich (2010), Carbonara et al. (2019) assume that entrepreneurial talent and business quality are complementary. In contrast to the other models, they also allow founders to become portfolio entrepreneurs, i.e., to run several businesses at a time. They assume that entrepreneurial skills positively influence the marginal productivity of the capital employed, where low-to-medium entrepreneurial talent is associated with decreasing returns and high entrepreneurial talent with constant returns. As a result, low- and medium-skilled entrepreneurs become portfolio entrepreneurs to compensate for weak productivity in their first business only to close down after the first round if they find poor diversification opportunities. High-skilled entrepreneurs are more likely to close down after the first round because they do not gain from portfolio entrepreneurship. ${ }^{4}$ Therefore, the minimum quality of the business in the first round must be higher to keep them in entrepreneurship. The implication from this model for our question is that the average ability of those who close is higher than that of novice entrepreneurs.

\footnotetext{
${ }^{4}$ Because the marginal productivity of capital for high-skilled entrepreneurs is constant, shifting capital between businesses has no effect on marginal productivity.
} 


\subsubsection{From failure to restart}

Up to this point, the above considerations relate to the first part of the selection process and describe the expected ability of a given cohort of founders who fail compared with that of novice entrepreneurs. The next question is: What is the expected ability of people who start anew after failure compared to that of novices? The Jovanovic (1982) model tells us nothing about this because restarting after failure is not considered to be an option. By contrast, in the study by Holmes and Schmitz (1990), all failed entrepreneurs start anew. ${ }^{5}$ Again, it depends on the level of transaction costs whether the average ability level of restarts after failure is higher or lower than that of novices. If transaction costs are sufficiently low, the average ability of restarters will be lower; in all other cases, it will be higher. From the Plehn-Dujowich (2010) model, we can derive the hypothesis that the average ability of restarters is definitely higher because only the entrepreneurs with high entrepreneurial talent take a second chance. The same applies to the model by Carbonara et al. (2019), where only the highly skilled close down a business and start another one.

All in all, the literature tends to support the view that failed entrepreneurs of a cohort of novice entrepreneurs are those with on average lower entrepreneurial talent, but that those who restart after failure have on average higher entrepreneurial talent than novices. The human capital approach suggests that failure experience is a learning opportunity of entrepreneurs and that we have a positive selection of entrepreneurs with respect to entrepreneurial talent at the end of the closure-restart process. This allows us to formulate the following hypothesis as a basis for further analysis:

Hypothesis:

The current businesses of failed entrepreneurs are likely to last longer than the business of novice entrepreneurs.

\footnotetext{
5 This is because people specialize in starting businesses. The setup of the model implies that, above a certain level of ability, starting a business is always the better option. This means that those who ever start a business run this business forever or repeatedly start new businesses (either following a sale of the business or a failure). Holmes and Schmitz (1990) do not allow for the possibility that entrepreneurs become employees.
}

\section{Data and estimation method}

\subsection{Data}

For our empirical analysis, we use data from the start-up panel maintained by the Leibniz Centre for European Economic Research (ZEW) Mannheim, Germany. We chose this dataset because it provides detailed information at both the individual and the firm level, including previous entrepreneurial experience of the founders of the businesses. In addition, it is a large representative dataset of all start-ups in Germany, which allows us to make statements about an entire population of entrepreneurs and their firms. In 2008, the dataset was jointly initiated by ZEW, KfW Bankengruppe (Germany's largest state-owned promotional bank), and Creditreform (Germany's largest credit rating agency) in order to provide representative information on start-ups and young firms in Germany. The project team has undergone some changes since the Start-up Panel was introduced. Currently, the panel is run by ZEW together with the Institute for Employment Research (IAB) of the German Federal Employment Agency and Creditreform, with the latter providing contact information for the gross sample. In the following, we refer to the panel as the IAB/ZEW Start-up Panel (or simply: Start-up Panel).

The sampling frame, i.e., the parent dataset for the IAB/ZEW Start-up Panel, is the Mannheim Enterprise Panel (Mannheimer Unternehmenspanel (MUP)), which contains basic information (firm addresses, year of start-up, sector of activity, and legal form) for nearly all German firms including start-ups (see Bersch et al. (2014) for a detailed description). ${ }^{6}$ The Start-up Panel is drawn from this dataset. It is a random sample from all sectors of the MUP population-except the primary sector, the energy sector, and the public sector-and encompasses independent new ventures founded in the 3 years prior to the year

\footnotetext{
${ }^{6}$ There is a registration lag for some of the new businesses in Germany in the MUP. This applies primarily to very small firms and those with minor economic activity. Our results could be biased if the business of novices and failures would be differently affected by this delay. We know that the registration delay is mainly determined by a firm's legal form. Because we control for the legal form in our estimations, we take potential differences between the businesses of novices and failures in this respect into account in our analyses.
} 
of the survey. Subsidiary businesses and ventures that resulted from merger activities are excluded from the Start-up Panel. Businesses that participate once in the survey are subsequently followed in successive panel years until they are 7 years old. ${ }^{7}$ The sample is stratified according to the year of the firm's formation and the sector of activity of the business. We control for the stratification of the sample by including dummy variables for start-up year and sector in all our regressions.

The panel data are collected using computer-aided telephone interviews and provide information about the founders' characteristics (i.e., self-employment experience, educational background, gender, managerial and leadership experience, motivation for start-up) and venture characteristics (i.e., innovation and $\mathrm{R} \& \mathrm{D}$ activities, financial situation, firm size). The panel does not indicate whether the current venture of the entrepreneur closes or is still in existence in a given year (our dependent variable). We take these data from the MUP, which contains information about whether a firm survives a given year, is voluntarily dissolved, or goes bankrupt. The MUP provides an independent data source and prevents common-method bias. To control for regional effects, we supplement the panel data with information on the INKAR database of the Federal Institute for Research on Building, Urban Affairs and Spatial Development.

We draw on information from the first nine survey waves from the Start-up Panel, which contain information on about 21,200 firms established between 2005 and 2015. As we do not know who in a team has self-employment experience, we restrict our sample to the businesses of sole entrepreneurs, i.e., to those that are founded by a single person. These businesses may still have employees, which we control for by including the number of employees in the estimations. This leaves us with around 14,800 firms. We run additional regressions where we include team

\footnotetext{
7 For a detailed description, see Fryges et al. (2010). Because participation in the Start-up Panel is voluntary, we do not have a response for every business in every year after the first contact. As a result, there is a noticeable difference in the number of observations depending on whether we consider timevarying variables in our regressions. We checked whether this influences our findings by comparing the results with and without time-varying variables included in the set of our control variables. The results vary little between the two versions of the model (see also footnote 12).
}

start-ups to find out to what extent our results are affected by restricting the sample on sole entrepreneurs. In the next section and in the online appendix to this paper, we present the results in the form of a robustness check.

\subsection{Variables}

\subsubsection{Dependent variables}

In our dataset, we record for each firm whether or not it has survived a given year. This information provides the basis for our first dependent variable. It is " 1 " if a firm survived and " 0 " if it is closed. (See Section 3.2.4 where we describe our estimation method.) As increasingly recognized in the literature, firm closure can have several reasons and is often not synonymous with failure (Headd, 2003; Wennberg et al, 2010). The MUP provides information about the type of closure event, so we can identify whether an entrepreneur had to leave the market due to bankruptcy or whether s/he closed her business for other reasons. This is valuable because if we found that failed entrepreneurs are less likely to go bankrupt than novice entrepreneurs this could be interpreted as an indication that failed entrepreneurs are in principle able to recognize danger, or that they have learned from previous experience so that second-time closures are "intelligent failures" (Sitkin, 1992). Therefore, we created an alternative dependent variable in which we split up the closure event into cases where the current business is closed voluntarily and cases where it goes bankrupt (see Section 3.2.4).

\subsubsection{Independent variable of interest}

Our right-hand side variable of main interest is a dummy, indicating whether or not an entrepreneur experienced a failure event with a business in the past. For this variable, we resort to two interrelated questions from the questionnaire of the start-up panel. The first is: "Have you ever started a business prior to the founding of this company?" If the interviewed entrepreneur answered "yes" to this question s/he received, a follow-up question asking what happened to the previous business. From this, we record whether the previous business still exists, was passed on to a successor, was sold, went bankrupt, or closed without a bankruptcy procedure. We define failed 
entrepreneurs to be those who went bankrupt with their previous business or closed their business without a formal bankruptcy procedure. We include the latter in our definition of failed entrepreneurs because a firm closure is likely to be an indication of the fact that the business did not stand the market test. Of course, there are other reasons to close down a business, such as bad health of the entrepreneur, the wish for retirement, or incidents in the family. While we do not know the exact reason why entrepreneurs voluntarily dissolved their businesses, we know from previous research on young firm closure in Germany that many entrepreneurs who close their business without filing for bankruptcy do this in order to prevent bankruptcy (Egeln et al. 2010). In our estimations, we nevertheless check whether there are differences between the two types of failed entrepreneurs.

Because we are interested in the relationship between failure experience and survival in the current venture, we exclude all entrepreneurs who ran a business before but did not experience a failure event. Thus, our variable "failure" is " 1 " for previously failed entrepreneurs and " 0 " for novice entrepreneurs. This further restriction leaves us with a final sample of around 9,700 firms (1,372 firms of formerly failed entrepreneurs and 8,285 firms for novices).

\subsubsection{Control variables}

We include a series of control variables in our regressions based on the information in the Start-up Panel. The first group of variables covers individual-specific information on the founders. It includes gender, educational degree, founder's age, years of industry experience, management experience, and main motive for setting up the current business. A second group of control variables refers to the characteristics of the new businesses. It includes the number of employees, whether the firm is a limited company, whether it conducts $\mathrm{R} \& \mathrm{D}$, investments, retained earnings, whether it got external financing, whether it got public funding, and whether it has experienced financial problems. We also control for the sector of business activity, GDP per capita, and the unemployment rate of the district ("Landkreis") in which the business is located, the start-up year, and the reporting year. The exact definition of our variables is given in Table 4 in the Appendix.
In Table 3 in the Appendix, we provide descriptive statistics including correlations between our variables for the estimation sample (firm/year observations). Around $10 \%$ of the observations belong to current businesses that are closed down in the period of observation of this study. In three-fifths of the cases (6\% of all observations), this occurs via dissolving the firm without a formal bankruptcy procedure. Two-fifths of the cases (4\% of all observations) are related to firms that go bankrupt. $14 \%$ of the observations are from firms whose entrepreneurs experienced a previous failure event with another business, most of which were voluntary dissolutions (82\%). The correlation part of the table shows that the correlation coefficients are not particularly high.

\subsubsection{Estimation method}

To estimate the survival time of the ventures, we employ a duration model. While survival time is continuous, we observe only whether or not the venture still exists at the end of the year. Since spell lengths are observed only in intervals, we estimate a model for interval-censored data. The relevant hazard rate is the probability of exit during year $j$ given a survival up to year $j-1$

$$
h_{j}(X)=P(j-1<T \leq j \mid T>j-1, X),
$$

where $j$ denotes the half-open interval (year $_{j-1} ;$,year $_{j}$ ]. Duration models based on this type of data can be estimated by applying methods for standard binary outcome models on a dataset with one row per firm and survival year (Sueyoshi, 1995; and Jenkins, 2005). ${ }^{8}$ The dependent variable contains the information whether or not venture $i$ survived year $j$

$S_{i j}=\left\{\begin{array}{l}1 \text { if } \text { firm } \mathrm{i} \text { survives year } \mathrm{j} \\ 0 \text { if firm } \mathrm{i} \text { does not survive year } \mathrm{j}\end{array}\right.$.

For the hazard rate function, we use the logistic distribution and allow for both time-invariant and time-variant covariates. The hazard rate for firm $i$ can then be expressed as

\footnotetext{
8 Thus, one observation is a firm-year combination, and the probability of surviving the following year is estimated.
} 
$h_{i j}=\frac{\exp \left(\beta_{0}+\beta_{1} X_{i}+\beta_{2} Z_{i j}\right)}{1+\exp \left(\beta_{0}+\beta_{1} X_{i}+\beta_{2} Z_{i j}\right)}$,

where $X_{i}$ is a matrix of time-invariant and $Z_{i j}$ is a matrix of time-variant explanatory variables. In order to allow the hazard rate to vary with survival time (duration dependence), year dummies are added to the list of regressors.

To account for the two types of closure (voluntary closure and bankruptcy), we apply a competing risk model. Because of the way survival time is reported in our data, we again use a model for interval-censored data. The dependent variable is

$S_{i j}=\left\{\begin{array}{l}0 \text { if firm i survives year } \mathrm{j} \\ 1 \text { if firm i voluntarily exists in year } \mathrm{j} . \\ 2 \text { if firm i goes bankrupt in year } \mathrm{j}\end{array}\right.$.

It can be shown that a competing risk model with interval-censored data can be estimated by applying a standard multinomial logit model (Allison, 1982; Jenkins, 2005). The destination-specific hazards for the two exit states in this case are assumed to be

$h_{v c}=\frac{\exp \left(\beta_{v c} X\right)}{1+\exp \left(\beta_{v c} X\right)+\exp \left(\beta_{b} X\right)}$

and

$h_{b}=\frac{\exp \left(\beta_{b} X\right)}{1+\exp \left(\beta_{v c} X\right)+\exp \left(\beta_{b} X\right)}$

where $v c=$ voluntary closure and $b=$ bankruptcy. Duration dependence is accounted for by including year dummies in the list of regressors as above.

Our preferred models are a pooled logit for the single risk case and a pooled multinomial logit for the competing risk case. We checked whether this choice has an impact on our results (see also Section 4.3 in the next chapter).

\section{Results}

\subsection{Comparing failed entrepreneurs and novices}

We start the presentation of our results with a comparison of novice entrepreneurs and entrepreneurs who failed with a previous venture in the start-up year of the current venture (Table 1). Failed entrepreneurs differ from novice entrepreneurs in several respects. Regarding educational degree, failed entrepreneurs are more likely than novices to have a university degree or no educational degree, are less likely to have a mastercraft qualification and are no more likely to have a vocational training degree. Overall, failed entrepreneurs have a similar degree of formal education to that of novices. By contrast, they are older-i.e., have more life and probably also more work experience-and spent more time working in the industry of the current business than novices do. However, they are less likely to have experience as a senior manager. ${ }^{9}$ Furthermore, the fraction of females is lower among failed entrepreneurs than among novices. Regarding start-up motives, the most important reason for failed entrepreneurs to set up a business is the wish to work independently. In that, they do not differ from novices. However, they are a bit less likely to state this reason than novices. Instead, they are more likely to indicate that they want to exploit an opportunity. In addition, they are less likely than novices to start a business because they do not have other options, i.e., because they are necessity entrepreneurs.

As with the personal characteristics, the characteristics of the businesses of failed entrepreneurs differ from those of novices. Most notably, the businesses of failed entrepreneurs have less financial resources than those of novice entrepreneurs. The fraction of financial capital they can attract from external sources is lower than that of novice entrepreneurs, they are less likely to receive government funding, ${ }^{10}$ and they

\footnotetext{
9 This is on account of how managerial experience is recorded in the IAB/ZEW Start-up Panel. The question of managerial experience was posed only to those who worked as employees immediately before starting the current business. Failed entrepreneurs worked significantly less frequently in paid employment before founding. If the sample is restricted to former employees, the fractions are reversed: failed entrepreneurs are significantly more likely to have experience as a senior manager.

${ }^{10}$ The fraction of firms receiving government funding may seem high both for novices and for entrepreneurs who fail. The reason for this is that the corresponding question in the start-up panel is quite broad and covers subsidies from all sorts of sources (EU, federal level ("Bund"), federal state level ("Länder"), municipalities ("Gemeinden”)) including those from the federal employment agency ("Bundesagentur für Arbeit"). The latter provides start-up subsidies for the unemployed. Overall, nearly one-third of young companies receive
} 
Table 1 Comparison of novices and failures in start-up year of current venture

\begin{tabular}{|c|c|c|c|c|c|}
\hline & $\begin{array}{l}\text { Novices } \\
\text { Mean }\end{array}$ & $\begin{array}{l}\text { Failures } \\
\text { Mean }\end{array}$ & Pearson's $X^{2}(1)$ & t-value & Sig \\
\hline \multicolumn{6}{|l|}{ Entrepreneur's human capital characteristics } \\
\hline Degree qualification $(\mathrm{y} / \mathrm{n})$ & 29.19 & 32.80 & 7.36 & & $* * *$ \\
\hline Mastercraft qualification (y/n) & 30.31 & 24.14 & 21.52 & & $* * *$ \\
\hline Vocational training (y/n) & 36.15 & 37.42 & 0.81 & & \\
\hline No educational degree $(\mathrm{y} / \mathrm{n})$ & 4.16 & 5.54 & 5.38 & & $* *$ \\
\hline Founder's age (years) & 37.91 & 42.23 & & -15.18 & $* * *$ \\
\hline Experience in industry (years) & 13.06 & 15.16 & & -7.80 & $* * *$ \\
\hline Managerial experience $(\mathrm{y} / \mathrm{n})$ & 43.19 & 31.65 & 64.36 & & $* * *$ \\
\hline Female $(y / n)$ & 15.85 & 11.08 & 20.80 & & $* * *$ \\
\hline Motive: opportunity (y/n) & 25.05 & 28.79 & 8.67 & & $* * *$ \\
\hline Motive: necessity (y/n) & 19.09 & 16.98 & 3.44 & & $*$ \\
\hline Motive: independence (y/n) & 44.13 & 41.69 & 2.84 & & $*$ \\
\hline \multicolumn{6}{|l|}{ New business characteristics } \\
\hline Number of employees & 2.48 & 2.48 & & -0.87 & \\
\hline Financing problems (y/n) & 16.13 & 21.93 & 16.35 & & $* * *$ \\
\hline Government funding (y/n) & 31.51 & 20.48 & 68.31 & & $* * *$ \\
\hline Retained earnings (\% of cash-flow) & 29.48 & 33.64 & & -3.34 & $* * *$ \\
\hline External financial capital ( $\%$ from ext. sources) & 12.36 & 9.32 & & 3.93 & $* * *$ \\
\hline Investments (thousand $€$ ) & 51.97 & 52.08 & & -0.03 & \\
\hline $\mathrm{R} \& \mathrm{D}(\mathrm{y} / \mathrm{n})$ & 13.66 & 19.10 & 16.47 & & $* * *$ \\
\hline Limited company & 29.40 & 46.27 & 135.76 & & $* * *$ \\
\hline \multicolumn{6}{|l|}{ Sectors ${ }^{1}$} \\
\hline New technology-based manufacturing & 9.91 & 10.06 & 0.03 & & \\
\hline New technology-based services & 15.75 & 20.77 & 21.58 & & $* * *$ \\
\hline Software & 4.48 & 8.89 & 47.34 & & $* * *$ \\
\hline Non-high-tech manufacturing & 12.71 & 9.40 & 11.99 & & $* * *$ \\
\hline Knowledge-intensive services & 5.73 & 7.14 & 4.19 & & $* *$ \\
\hline Other business services & 7.31 & 9.11 & 5.43 & & $* *$ \\
\hline Consumer services & 13.31 & 11.37 & 3.92 & & $* *$ \\
\hline Construction & 15.62 & 12.17 & 10.89 & & $* * *$ \\
\hline Retail & 15.17 & 11.08 & 15.83 & & $* * *$ \\
\hline \multicolumn{6}{|l|}{ Regional characteristics } \\
\hline Unemployment rate & 7.58 & 7.44 & & 1.25 & \\
\hline GDP per capita (thousand $€$ ) & 32.15 & 33.33 & & -2.68 & $* * *$ \\
\hline
\end{tabular}

Note: ${ }^{1}$ The respective NACE codes of the sector aggregates can be found in Table 4 in the Appendix

Source: IAB/ZEW Start-up Panel; authors' calculation

are more likely to experience financial problems. As a consequence, they use more internal resources for

Footnote 10 (continued)

support from public support programs in Germany, with 20\% receiving funding from the federal employment agency. financing. Overall, it seems that potential investors treat past business failure as a bad signal for future performance. Plausibly, failed entrepreneurs choose the limited company as legal form for their business significantly more often. This can be interpreted as a personal risk reduction strategy in the face of a potentially underfinanced business. However, the lower 
Fig. 2 Estimated survivor function (Kaplan-Meier) Source: IAB/ZEW Start-up Panel; authors' calculation

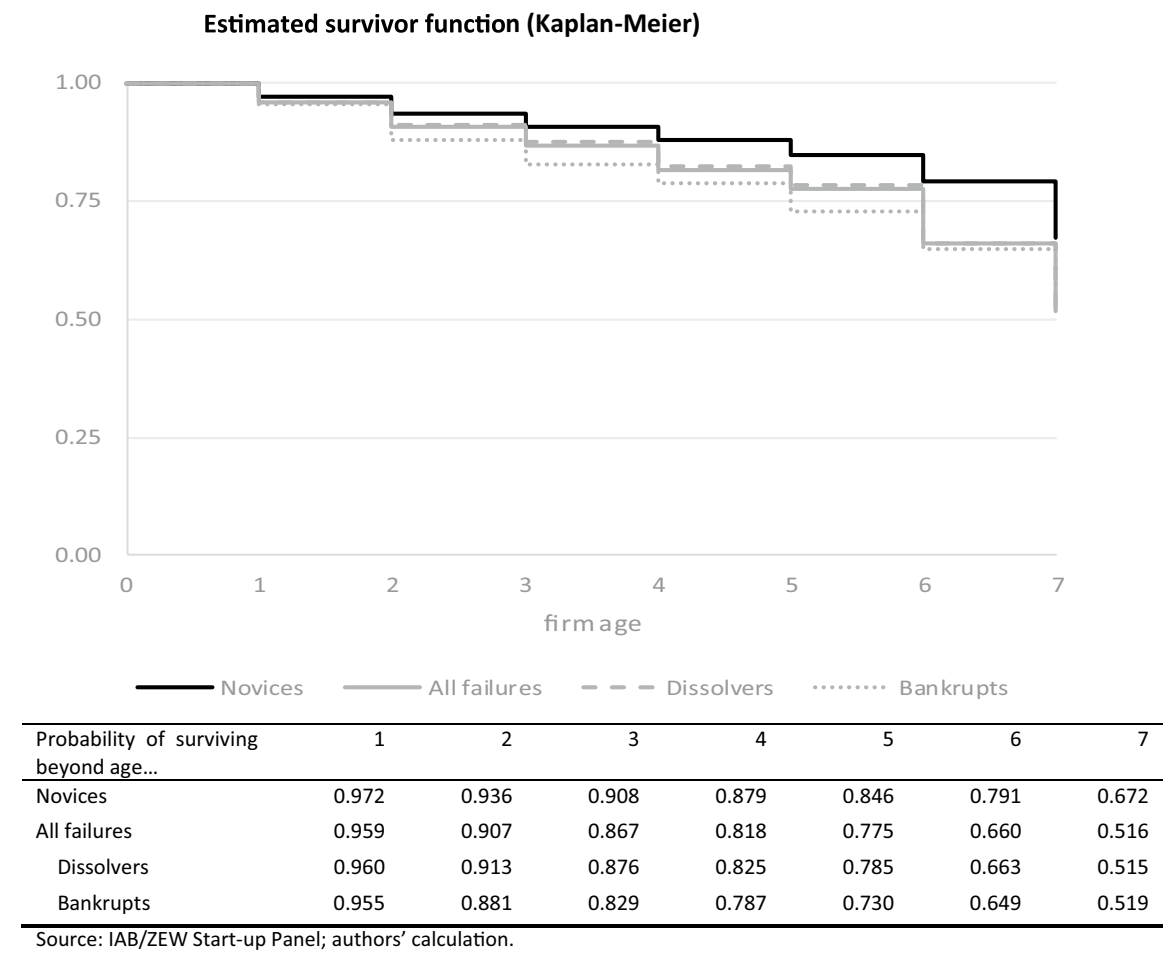

financial resources do not prevent entrepreneurs from performing R\&D more often than novices.

Regarding the sector of activity, failed entrepreneurs set up their businesses more often than novices in new technology-based services, software, knowledge-intensive services, and other business services and less often in non-high-tech manufacturing, consumer services, construction, and retail. With respect to the physical location, we find that failed entrepreneurs tend to set up businesses in regions with a higher GDP per capita.

All in all, while there are some similarities between failed entrepreneurs and novices, there are a series of significant differences. This supports our conjecture that failed entrepreneurs are not a random sample of all entrepreneurs, which is to say that selection indeed plays a role. We control for these factors in our regressions to exclude the possibility that our results are driven by observed differences.

Figure 2 shows the Kaplan-Meier estimates of the survivor function. What we can see from this figure is that the businesses of entrepreneurs who have a previously failed business have a lower likelihood of reaching a certain age. While in the beginning the survival probabilities are quite close, they start to diverge from age 2 where the difference between the likelihood of surviving beyond this age is 3 percentage points lower for failures than for novices. Only $52 \%$ of the business of previously failed entrepreneurs make it to the age of 7 , while $67 \%$ of the businesses of novices do. When we look at the businesses of founders who previously went bankrupt, the survival rate decreases even faster. This gives a first indication of the relationship between failure experience and current business survival. In the following, we analyze this relationship with multivariate regressions.

\subsection{Regression results}

Table 2 shows the results of our regressions. ${ }^{11}$ Note that in columns (1) and (4), the dependent variable is the binary variable survival of the following year,

\footnotetext{
11 In this specification and in the other regressions we run for this paper, we only allowed the intercept to vary with failure experience. We also looked into the shape of the baseline hazard over time for novices and failures. Because we found that this does not differ much between the two groups, we regard only including an intercept and a dummy indicating failure experience to be a reasonable simplification.
} 
Table 2 Relationship between failure experience and new business closure, marginal effects

Dep. var.: survival Dep. var.: survival/voluntary of the following dissolution/bankruptcy of/in the year $(\mathrm{y} / \mathrm{n})$

(1)

$-0.038 * * *$

(0.006)

Failure experience

Dissolution

Bankruptcy

Degree qualification

$0.014 * *$

(0.006)

Mastercraft qualification

$0.029 * * *$

(0.006)

Female

$-0.011 *$

(0.006)

Founder's age

$0.036 * * *$

(0.011)

Industrial experience

$0.013 * * *$

(0.003)

Managerial experience

$(0.005)$

Opportunity

$-0.001$

(0.006)

Necessity

$-0.016 * * *$

(0.006)

Size

$-0.009^{* * *}$

(0.003)

Limited company

0.002

(0.006)

R\&D

$-0.000$

(0.007)

Investment

$0.008 * * *$

(0.002)

Investment dummy $\quad 0.045^{* *}$

(0.021)

Retained earnings

$0.040 * * *$

(0.007)

External funding

$-0.001$

(0.009)

Government funding $\quad 0.012 * *$

(0.005) following year

\begin{tabular}{ll}
\hline Failure event 1: & Failure event \\
dissolution & 2: bankruptcy
\end{tabular}

(2)

(3)

$0.021 * * *$

(0.005)

$0.019 * * *$

(0.004)
Dep. var.: survival Dep. var.: survival/ voluntary of the following dissolution/bankruptcy of/in year $(y / n)$ the following year

Failure event Failure event 1: dissolution 2: bankruptcy

(4)

(5)

(6)
$-0.033 * * *$

(0.007)

$-0.065 * * *$

(0.012)

$-0.017 * * *$

$0.014 * *$

(0.005)

$-0.015 * * *$

(0.005)

0.006

$(0.005)$

$-0.024 * * *$

(0.009)

$-0.008 * * *$

(0.003)

$-0.005$

(0.004)

$-0.002$

(0.004)

0.004

(0.005)

$-0.008 * * *$

(0.003)

$-0.017 * * *$

(0.005)

0.000

(0.005)

$-0.006^{* * *}$

(0.002)

$-0.038 * *$

(0.016)

$-0.032 * * *$

(0.006)

$-0.002$

(0.007)

$-0.013 * * *$

(0.004)
(0.004)

$-0.013 * * *$

(0.006)

$0.029 * * *$

(0.004)

0.005

(0.004)

$-0.012 *$

(0.007)

$-0.004 *$

(0.002)

0.001

(0.003)

0.004

(0.004)

$0.013 * * *$

(0.004)

$0.013 * * *$

(0.002)

$0.014 * * *$

(0.004)

0.002

(0.004)

$-0.002$

(0.001)

$-0.001$

(0.014)

$-0.009 *$

(0.005)

0.001

(0.005)

0.002

(0.003)
(0.006)

$-0.011^{*}$

(0.006)

$0.038 * * *$

(0.011)

$0.013 * * *$

(0.003)

0.002

(0.005)

$-0.001$

(0.006)

$-0.016 * * *$

(0.006)

$-0.009 * * *$

(0.003)

0.002

(0.006)

$-0.000$

(0.007)

$0.008 * * *$

(0.002)

$0.045 * *$

(0.021)

$0.040 * * *$

(0.007)

$-0.001$

(0.009)

$0.012 * *$

(0.005)
$0.020 * * *$

(0.005)

$0.022 * *$

(0.011)

0.003

(0.005)

$-0.015^{* * *}$

(0.005)

0.006

(0.005)

$-0.024 * * *$

(0.009)

$-0.008 * * *$

(0.003)

$-0.005$

(0.004)

$-0.002$

(0.004)

0.004

(0.005)

$-0.008 * * *$

(0.003)

$-0.017 * * *$

(0.005)

0.000

(0.005)

$-0.006 * * *$

(0.002)

-0.038 **

(0.016)

$-0.032 * * *$

(0.006)

$-0.002$

(0.007)

$-0.013 * * *$

(0.004)
$0.013 * * *$

(0.004)

$0.039 * * *$

(0.007)

$-0.017 * * *$

(0.004)

$-0.013 * * *$

(0.004)

0.005

(0.004)

$-0.014 * *$

(0.007)

$-0.004 * *$

(0.002)

0.002

(0.003)

0.004

(0.004)

$0.013 * * *$

(0.004)

$0.013 * * *$

(0.002)

$0.014 * * *$

(0.004)

0.002

(0.004)

$-0.002$

(0.001)

$-0.002$

(0.014)

$-0.009 *$

(0.005)

0.002

(0.005)

0.002

(0.003) 
Table 2 (continued)

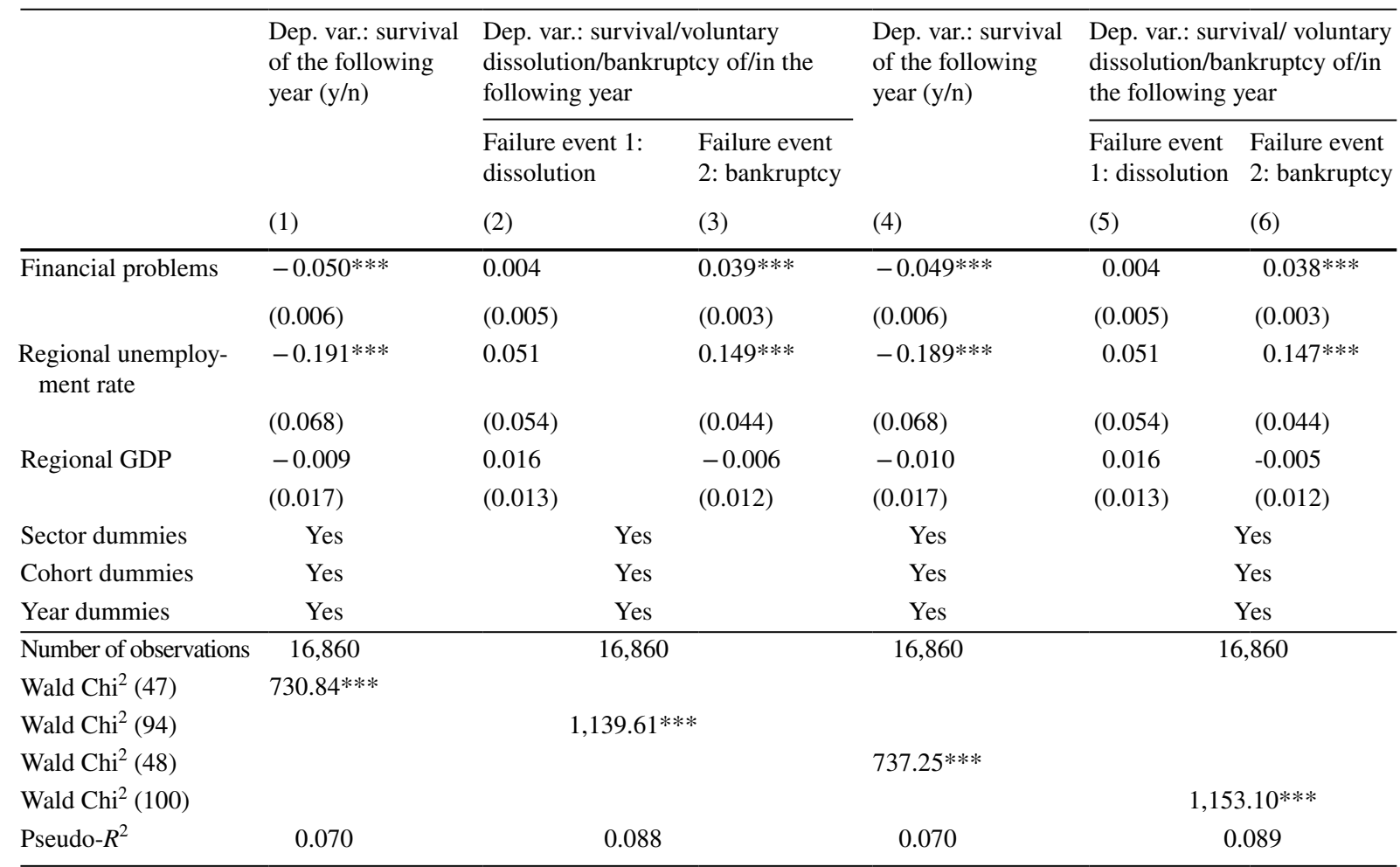

Standard errors in parentheses. $* * *, * *$, depict significance at the $1 \%, 5 \%$, and $10 \%$ level, respectively, and correspond to the test of the underlying coefficient being zero. The reference categories are formal education, apprenticeship, no formal education, and independence-centered start-up motivation

Source: IAB/ZEW Start-up Panel; authors' calculations

while the dependent variable in columns (2) and (3) as well as columns (5) and (6) is the ternary variable survival/voluntary dissolution/bankruptcy of the following year as defined in Section 3.2.4. A positive effect in columns (1) and (4) means that the probability of survival increases while a positive effect in the other columns indicates an increased probability of the respective failure event.

Our regression equation makes sense because the control variables have the expected signs: Firms managed by better-educated entrepreneurs (degree and mastercraft qualification) and by those with industrial and life experience are more likely to survive (see also e.g. Lin et al., 2000, Bates, 1995, and van Praag, 2003). Firms that invest more and those who receive government funding are more likely to survive, while financial problems increase the likelihood of failure. ${ }^{12}$

\footnotetext{
12 These variables along with the number of employees, the percentage of retained earnings, the percentage of external funding, and whether a company does R\&D are potentially
}

Finally, firms that are located in districts with higher unemployment rates have lower survival chances.

With respect to our main variables of interest, it turns out that previously failed entrepreneurs have a lower likelihood of surviving with their current venture than do novice entrepreneurs (column (1)). Compared with the estimated average baseline probability in the population of $83 \%$, they have a 3.8 percentage point lower probability of surviving the following year with their venture. When we look at the type

Footnote 12 (continued)

endogenous. We ran robustness checks where we excluded these variables. This also determines whether it matters that we do not have an observation for every business and every year because the potentially endogenous variables happen to be the time-varying variables in our model (see footnote 7). The results do not differ much from those where we include these variables. The result tables of these estimations are available on request. 
of market exit of the current venture, we can see that failed entrepreneurs are more likely to leave the market by dissolving their business and to go bankrupt than novices (columns (2) and (3)). Thus, the higher closure rate of failed entrepreneurs cannot be fully attributed to "intelligent failure," i.e., to the fact that entrepreneurs test a business idea and close the business down when the idea turns out not to be viable.

This impression is reinforced by looking at the two types of failed entrepreneurs separately. Both, entrepreneurs who dissolved their previous business without a formal bankruptcy procedure and those who went bankrupt with their previous business are less likely to survive with their current venture than novice entrepreneurs (column (4)). Furthermore, both types are more likely to leave the market via bankruptcy than novice entrepreneurs (column (6)). For entrepreneurs with bankruptcies behind them, these effects are particularly strong. The businesses of these entrepreneurs are 6.2 percentage points less likely to survive the following year than novices, which is quite substantial compared with the estimated average survival probability in the population. In addition, they have a 3.9 percentage point higher probability of going bankrupt than novices (column (6)), which is one of the highest estimated effects of failure experience on the survival probability of the current venture. Overall, with these results, we must reject the hypotheses formulated in Section 2. Failed entrepreneurs survive shorter rather than longer with their current venture.

\subsection{Robustness checks}

The results presented above show that the businesses of failed entrepreneurs have lower survival chances and that they are more likely to close the business with and without a bankruptcy procedure than novices. However, these results are the average effects for the whole group of failed entrepreneurs. An interesting question is: Do these results hold for all failed entrepreneurs or are there circumstances where these relationships do not apply? In addition, we imposed restrictions on our sample and our estimation approach by excluding team start-ups and running pooled regressions without explicitly taking unobserved heterogeneity into account. To check whether the focus on all entrepreneurs and the restrictions in the analyses influence the outcomes of our analyses, we ran a series of robustness checks. To be specific, we divided the entrepreneurs into subgroups according to their human capital characteristics, looked at incorporated businesses in detail, replaced the dummy variable "failure experience" with the number of failure events in the past, controlled for the possibility that failed entrepreneurs run riskier projects, ran versions of our regressions where we included teams, and tried to control for unobserved heterogeneity. The overall summary of the outcome of these analyses is that the results do not differ much from our main results. Thus, what we see in Table 2 holds for a variety of groups and situations. The details of the robustness checks can be found in the online appendix to this paper.

\section{Summary and discussion}

It is commonly assumed that failed entrepreneurs have higher chances of success than novices when starting a new business. This hypothesis is mainly based on the argument that higher human capital leads to better economic outcomes and failed entrepreneurs have the chance to increase their human capital through learning from their experience. Failure is assumed to be a particularly rich source of learning because it can induce entrepreneurs to think about underlying assumptions of their actions and to adjust their behavior.

Another mechanism that can support the above hypothesis is selection in the closure and restart process of experienced entrepreneurs. Selection has only recently been included in the discussion, but we think it is important for understanding the observed outcomes of failed entrepreneurs with their subsequent businesses. Following the literature, we propose that the entrepreneurial talent of the individuals closing and restarting the businesses is an important driver of the selection process. Existing theoretical models suggest that a positive selection takes place so that failed entrepreneurs who start anew have higher entrepreneurial talent than novices. Thus, both human capital theory and selection led us to formulate the hypothesis that failed entrepreneurs survive longer with their current business than novices.

However, in this paper, we find that our data do not support this hypothesis. We see that failed entrepreneurs are less likely to survive than novice 
entrepreneurs. This holds both for entrepreneurs who voluntarily dissolved their past venture and those who went bankrupt with a previous venture. The latter group has a particularly high bankruptcy rate with the current venture. As shown in the online appendix, the result turns out to be robust when we look into different subgroups of entrepreneurs, consider the number of past failure events, control for the inclination of entrepreneurs pursuing risky projects, include teams, and control for unobserved heterogeneity.

\subsection{Interpretation}

The results of our analyzes contradict previous theoretical predictions. But considering selection alongside learning provides an explanation of the observed phenomenon, at least in a rough form.

It is possible that the outcome of the selection process is different from what existing theoretical models suggest. Failed restarters may have the same or less entrepreneurial ability than novices. Taking measurable human capital, such as the years of education, as a reflection of entrepreneurial talent, the empirical literature regarding the question of who restarts after failure does not completely rule out this conclusion. While Metzger (2006a), Hessels et al. (2011), Stam et al. (2008), and Carbonara et al. (2019) discover a positive effect of human capital on the probability to restart, Wagner (2003) Schutjens and Stam (2006) as well as Nielsen and Sarasvathy (2016) do not find an effect. Amaral et al. (2011) show with Portuguese register data that more educated entrepreneurs are less likely to start another business.

If the selection process means that the most able people do not start anew, the relationship between failure experience and survival with the current venture can also be non-positive and therefore different from that formulated in the main hypothesis in Section 2. In general, the interaction between ability and learning is likely to be quite complex but the negative sign of the estimated effect that we find can only be explained if failed entrepreneurs have less ability than novice entrepreneurs on average. Thus, our results suggest that failed entrepreneurs who start anew have lower-than-average entrepreneurial talent and that a learning effect is not sufficient to compensate for their lower ability.
An argument that is often put forward to explain why failed entrepreneurs start again despite poor chances of success is that they are forced to set up another business because they cannot find a job elsewhere. But this does not seem to be the case. As we can see from Table 1, only $17 \%$ of the failed entrepreneurs indicate that they had no other alternative than to restart and this fraction is even lower than that for novice entrepreneurs. Thus, the need of setting up a business is lower for failed entrepreneurs than for novice entrepreneurs. This is in line with Nielsen and Sarasvathy (2016), who find that failed entrepreneurs have a higher likelihood to restart even after controlling for necessity entrepreneurship. They thus conclude that the restart decision of failed entrepreneurs is little affected by restrictions in opportunities. Furthermore, our data does not indicate that failed entrepreneurs simply make attribution errors by blaming the external environment, and thus forego valuable industry experience, as Eggers and Song (2015) suggest. The failed entrepreneurs in our dataset have more industry experience than novices and we find a lower survival probability even though we control for industry experience.

Instead, what may be happening here is that cognitive biases prompt less talented failed entrepreneurs to start again. Previous studies have shown that entrepreneurs in general come from the group of over-optimistic and over-confident individuals (e.g., Arabsheibani et al, 2000; Camerer \& Lovallo, 1999; Cooper et al, 1988). Additionally, Ucbasaran et al. (2010) show that failed entrepreneurs do not adjust their level of optimism and confidence after a failure. Thus, they are as convinced that they are good entrepreneurs as before. Nielsen and Sarasvathy (2016) argue that failed entrepreneurs commit strong socalled Type II errors: They have both a higher likelihood of starting and closing again. They begin a new venture even though they seem to lack the right prerequisites. Restart after failure may also be an expression of a sort of behavioral addiction to entrepreneurship, as suggested by Spivack et al (2014).

\subsection{Implications}

What are the implications of our analysis? Given our results, a "second chance" policy that supports failed entrepreneurs cannot generally be justified. Failed 
restarters are more likely to waste resources than to generate value, which is harmful both for society and for the individual entrepreneur. Of course, we do not want to insinuate that all previously failed entrepreneurs are low-ability entrepreneurs and that it is not worth supporting high-risk innovation projects just because they originate from previously failed entrepreneurs. The Walt Disney's and Travis Kalanick's (Uber) of this world, who failed several times before they discovered a high-value business idea, do exist. It is also possible that talented failed entrepreneurs are discouraged from setting up another business because they are traumatized by the failure experience or lack the relevant (financial) resources. And Nielsen and Sarasvathy (2016) find that some former entrepreneurs do indeed avoid starting new ventures although they have good survival prospects and knowledge. Nor should one discount the positive external effects that arise when surviving firms build on the technology and knowledge generated by failed firms, as pointed out by Knott and Posen (2005) and Hoetker and Agarwal (2007). However, our analysis shows that on average previously failed entrepreneurs who start again perform worse than novices. A targeted search and support of high-profile entrepreneurs among the failed entrepreneurs seems to be more sensible than setting up a general second-chance policy.

\subsection{Limitations and further research}

The most obvious limitation of our study is that the information in our dataset does not allow us to disentangle entrepreneurial learning and entrepreneurial ability. In addition, we cannot support our conjecture that entrepreneurial talent is what drives our results. In other circumstances, we could have conducted a fixed-effects regression to test the conjecture, but our variable of interest is a dummy and would drop out in this kind of regression. Instead, we rely on a kind of "circumstantial analysis." Our arguments, we believe, are nevertheless plausible and are supported by the literature. We adopt the established conjecture that performance persistence in entrepreneurship is evidence of entrepreneurial talent and apply it consistently to previously failed entrepreneurs. However, further research is needed to validate this conjecture for the case of failed entrepreneurs. One way of doing this is to utilize panel data at the individual level, as e.g. Rocha et al. (2015) or Lafontaine and Shaw (2016) have done for the general entrepreneurial experience.

Another potential problem with our study is that it is carried out in only one country. Though our dataset is comprehensive and detailed, it is based exclusively on businesses in Germany, and hence could be biased due to particular circumstances in the German labor market and country-specific attitudes towards failure. Yet our extensive literature review-see Table A8 in the online appendix-shows that experienced entrepreneurs (failed or not) tend not to outperform novice entrepreneurs and, if they do, it is those who have been successful in the past who perform better than novice entrepreneurs. Thus, we are quite confident that our results are generalizable beyond the German context. Nevertheless, it would be interesting to conduct a cross-country analysis to check for institutional and cultural variations.

Another interesting avenue of research would be to focus more on teams. We excluded all team start-ups so as not to confound team effects with the effect of failure experience because the data does not indicate which team members have failure experience. However, failing and restarting in a team may lead to different outcomes in future ventures than for solo entrepreneurs because team members can discuss the failure event together, which may make drawing the right lessons easier. In addition, it would be interesting to investigate how failed solo entrepreneurs fare when they set up a new venture together with others. Though they may not be good entrepreneurs, their experience may benefit the team. Furthermore, teammates may compensate for weak entrepreneurial ability of previously failed solo entrepreneurs.

Finally, it would be worth investigating whether failed entrepreneurs have spillover effects on other entrepreneurs and firms and, if so, how much. The latter is important when assessing whether the social benefits of spillovers are larger than the private costs of failure. While Knott and Posen (2005) as well as Hoetker and Agarwal (2007) show that failure is associated with positive externalities; their focus lies on established firms, so that it is not clear whether their conclusions apply to young businesses as well. 


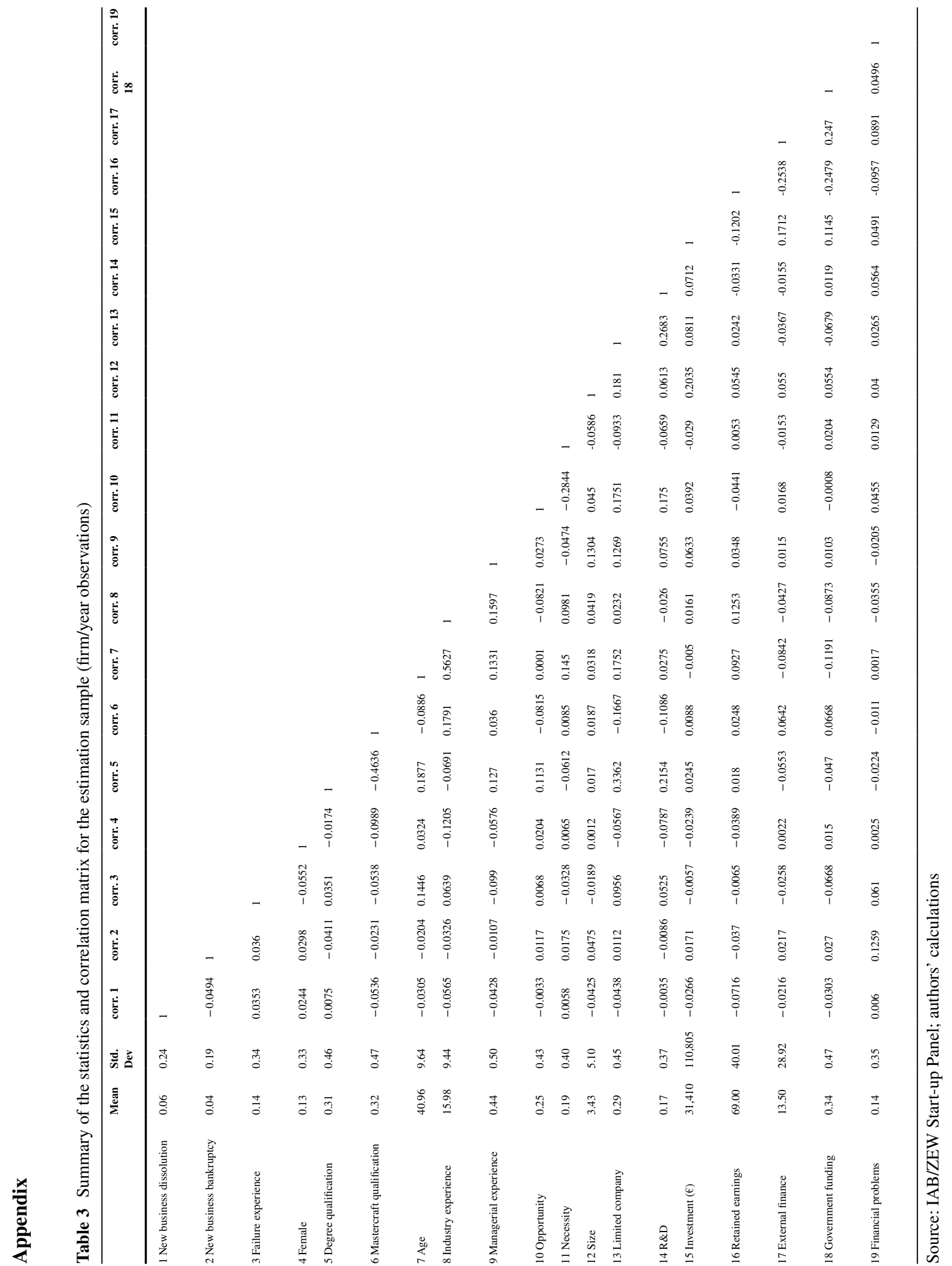


Table 4 Variable description

Variable description

Survival status - available in the Mannheim Enterprise Panel (Mannheimer Unternehmenspanel (MUP))

Exit 1

Survival status of the firm at the end of each year (binary) $1=$ active; $0=$ closed

Exit 2

Survival status of the firm at the end of each year (ternary) $-0=$ active; $1=$ voluntarily closed (liquidated or dissolved); $2=$ bankruptcy

Failure experience - available in the IAB/ZEW Start-up Panel Failure

$1=$ entrepreneur previously dissolved a business voluntarily or went bankrupt with a business (Voluntary dissolution does not include the sale of the business or the transfer to a successor. Thus, a business that has been dissolved voluntarily went out of the market.); $0=$ otherwise

Entrepreneurial human capital characteristics - available in the IAB/ZEW Start-up Panel

Female

Degree qualification

Mastercraft qualification

Vocational training

No education

Founder's age

Industrial experience

Managerial experience

Opportunity

Necessity

Independence

New firm characteristics - available in the IAB/ZEW Start-up Panel

Size

Limited company

$R \& D$

Investments/ investment dummy

Retained earnings

External funding

Government funding

Financial problems

High project risk

Team
$1=$ female $0=$ male

$1=$ highest degree of entrepreneur is a university degree; $0=$ otherwise

1 = highest degree of entrepreneur is German master craftsman diploma; $0=$ otherwise

$1=$ highest degree of entrepreneur is vocational training; $0=$ otherwise

$1=$ highest degree of entrepreneur is no education; $0=$ otherwise

Logarithm of the entrepreneur's age in years

Logarithm of the years of sectoral experience of the entrepreneur

$1=$ has previously been a senior manager in another business;

$0=$ otherwise

$1=$ main motivation to set up the business was based on a precise business idea or market gap; $0=$ otherwise

$1=$ main motivation to set up the business was because it was a way out of unemployment or because of the absence of adequate employment; $0=$ otherwise

$1=$ main motivation for setting up the business was to be independent. $0=$ otherwise (base category)

Logarithm of number of employees (full-time equivalent) (including the entrepreneur)

$1=$ business is private or public limited company; $0=$ otherwise (information available from the MUP dataset

$1=$ business conducted research and development activities; $0=$ otherwise

Logarithm of investment amount (without leasing and rents)/ investment dummy

Percentage share of operating costs and investments financed by cash flow and retained earnings

Percentage share of financial capital from external sources

$1=$ received government financial support; $0=$ otherwise

$1=$ had problems acquiring funding from external sources; $0=$ otherwise

$1=$ inclined or strongly inclined towards high-risk projects with high returns; $0=$ otherwise

$1=$ business has at least two founders; $0=$ otherwise 
Table 4 (continued)

\section{Variable description}

\section{Sectors - available in the IAB/ZEW Start-up Panel}

New technology-based manufacturing

New technology-based services

Software

Non-high-tech manufacturing

Knowledge-intensive services

Other business services

Consumer services

Construction

Retail

Foundation year

Reporting year

Regional characteristics - available in the INKAR database

Regional unemployment rate

Regional GDP
$1=$ business sector is new technology-based manufacturing; $0=$ otherwise (NACE Rev. 2: 20.20. 21.10. 21.20. 24.46. 25.40. 26.11. 26.20. 26.30. 26.40. 26.51. 26.60. 30.30. 30.40 . 32.50 / 20.13. 20.14. 20.16. 20.17. 20.41. 20.51. 20.53. 20.59 22.11. 22.19. 23.19. 26.70. 27.11. 27.12. 27.20. 27.40. 27.90. 28.11-15. 28.23. 28.24. 28.29. 28.30. 28.41. 28.49. 28.92-96. 28.99. 29.10. 29.31. 29.32. 30.20)

$1=$ business sector is a new technology-based service industry excluding software; $0=$ otherwise (NACE Rev. 2: 61.1-3. 62 (without 62.01). 63.1.71.1-2.72.1)

$1=$ business sector is the software industry; $0=$ otherwise (NACE Rev. 2: 62.01)

$1=$ business sector is a manufacturing industry outside NTB manufacturing; $0=$ otherwise (NACE Rev. 2: 10-33 (without NTB manufacturing))

1 = business sector is a knowledge-intensive service industry; $0=$ otherwise (NACE Rev. 2: 69.1-2. 70.2. 72.2. 73.1-2)

$1=$ business sector is another firm-related service industry; $0=$ otherwise (NACE Rev. 2: 49.2. 49.5. 50.2. 50.4. 51.2. 52. 53. 61.9. 63.9. 64. 74.1. 74.3. 74.9. 77.1. 77.3-4. 78. 80-82)

$1=$ business sector is another consumer-related service industry; $0=$ otherwise (NACE Rev. 2: 49.1. 49.3-4. 50.1. 50.3. 51.1. 55 56. 58-60. 65-66. 68. 74.2. 77.2. 79. 85.5-6. 90-93. 95-96)

$1=$ business sector is construction; $0=$ otherwise (NACE Rev. 2 : 41-43)

$1=$ business sector is the retail sector; $0=$ otherwise (NACE Rev. 2: 45-47 (without 46.1))

Year of business founding

Reporting year of the survey

Unemployment rate in the district of the location of the new business GDP per capita in the district where the new business is located (in $100 \mathrm{~T} €$ )
Funding Open Access funding enabled and organized by Projekt DEAL.

Open Access This article is licensed under a Creative Commons Attribution 4.0 International License, which permits use, sharing, adaptation, distribution and reproduction in any medium or format, as long as you give appropriate credit to the original author(s) and the source, provide a link to the Creative Commons licence, and indicate if changes were made. The images or other third party material in this article are included in the article's Creative Commons licence, unless indicated otherwise in a credit line to the material. If material is not included in the article's Creative Commons licence and your intended use is not permitted by statutory regulation or exceeds the permitted use, you will need to obtain permission directly from the copyright holder. To view a copy of this licence, visit http://creativecommons.org/licenses/by/4.0/.

\section{References}

Allison, P.D. (1982), Discrete time methods for the analysis of event histories, in S. Leinhardt (ed.). Sociological Methodology, Jossey-Bass, San Francisco, 61-98. DOI: https:// doi.org/10.2307/270718

Amaral, A. M., Baptista, R., \& Lima, F. (2011). Serial entrepreneurship: Impact of human capital on time to re-entry. Small Business Economics, 37, 1-21. https://doi.org/10. 1007/s11187-009-9232-4

Arabsheibani, G., de Meza, D., Maloney, J., \& Pearson, B. (2000). And a vision appeared unto them of a great profit: Evidence of self-deception among the self-employed. Economics Letters, 67(1), 35-41. https://doi.org/10.1016/ S0165-1765(99)00242-6 
Audretsch, D. B. (1991). New-firm survival and the technological regime. The Review of Economics and Statistics, 73(3), 441-450. https://doi.org/10.2307/2109568

Bates, T. (1995). Analysis of survival rates among franchise and independent small business startups. Journal of Small Business Management, 33(2), 26-36.

Bates, T. (2005). Analysis of young, small firms that have closed: Delineating successful from unsuccessful closures. Journal of Business Venturing, 20, 343-358. https:// doi.org/10.1016/j.jbusvent.2004.01.003

Baron, R. A., \& Ensley, M. D. (2006). Opportunity recognition as the detection of meaningful patterns: Evidence from comparisons of novice and experienced entrepreneurs. Management Science, 52(9), 1331-1344. https://doi.org/ 10.1287/mnsc. 1060.0538

Becker, G. (1967). Human capital: A theoretical and empirical analysis, with special reference to education. Columbia University Press.

Brüderl, J., Preisendörfer, P., \& Ziegler, R. (1992). Survival Chances of Newly Founded Business Organizations, 57(2), 227-242. https://doi.org/10.2307/2096207

Bersch, J., S. Gottschalk, B. Müller, and M. Niefert (2014), The Mannheim Enterprise Panel (MUP) and Firm Statistics for Germany, ZEW Discussion Paper Nr.14-104, Mannheim. DOI: https://doi.org/10.2139/ssrn.2548385

Brown, R. B. (2000). Contemplating the emotional component of learning. Management Learning, 31(3), 275-293. https://doi.org/10.1177/1350507600313001

Carbonara, E., Thu Tran, H., \& Santarelli, E. (2019). Determinants of novice, portfolio, and serial entrepreneurship: An occupational choice approach. Small Business Economics. https://doi.org/10.1007/s11187-019-00138-9

Camerer, C., \& Lovallo, D. (1999). Overconfidence and excess entry: An experimental approach. American Economic Review, 89(91), 306-318. https://doi.org/10.1257/aer.89.1. 306

Chen, J. (2013). Selection and serial entrepreneurs. Journal of Economics and Management Strategy, 22(2), 281-311. https://doi.org/10.1111/jems.12016

Coelho, P., \& McClure, J. E. (2005). Learning from failure, American. Journal of Business, 20(1), 13-20. https://doi. org/10.1108/19355181200500001

Cooper, A. C., Woo, C. Y., \& Dunkelberg, W. C. (1988). Entrepreneurs' perceived chances for success. Journal of Business Venturing, 3(2), 97-108. https://doi.org/10.1016/ 0883-9026(88)90020-1

Cope, J. (2003), Entrepreneurial Learning and critical reflection. Discontinuous events as triggers for 'higher-level' learning, Management Learning, 34(4), 429-450. DOI: https://doi.org/10.1177/1350507603039067

Cope, J. (2005). Toward a dynamic learning perspective of entrepreneurship. Entrepreneurship Theory \& Practice, 373-397,. $\quad$ https://doi.org/10.1111/j.1540-6520.2005. 00090.x

Dimov, D. (2010). Nascent entrepreneurs and venture emergence: Opportunity confidence, human capital, and early planning. Journal of Management Studies, 47(6), 11231153. https://doi.org/10.1111/j.1467-6486.2009.00874.x

Eesley, C. E., \& Roberts, E. B. (2012). Are you experienced or are you talented?: When does innate talent versus experience explain entrepreneurial performance? Strategic
Entrepreneurship Journal, 6(3), 207-219. https://doi.org/ 10.1002/sej.1141

Egeln, J., Falk, U., Heger, D., Höwer, D., \& Metzger, G. (2010). Ursachen für das Scheitern junger Unternehmen in den ersten fünf Jahren ihres Bestehens. Mannheim and Neuss: Bundesministerium für Wirtschaft und Technologie.

Eggers, J. P., \& Song, L. (2015). Dealing with failure: Serial entrepreneurs and the costs of changing industries between ventures. Academy of Management Journal, 58(6), 1785-1803. https://doi.org/10.5465/amj.2014. 0050

European Commission (2007), Overcoming the stigma of business failure - For a second chance policy. Implementing the Lisbon Partnership for Growth and Jobs, COM(2007) 584 final.

Frankish, J. S., Roberts, R. G., Coad, A., Spears, T. C., \& Storey, D. J. (2012). Do entrepreneurs really learn? Or do they just tell us that they do? Industrial and Corporate Change, 1464-3650, https://doi.org/10.1093/icc/dts016

Fryges, H., Gottschalk, S., \& Kohn, K. (2010). The KfW/ZEW Start-up Panel: Design and Research Potential. Schmollers Jahrbuch/journal of Applied Social Sciences Studies, European Data Watch, 130, 117-131. https://doi.org/10. 2139/ssrn.1494326

Gibb, A. (1997). Small firms' training and competitiveness: Building on the small business as a learning organization. International Small Business Journal, 15(3), 13-29. https://doi.org/10.1177/0266242697153001

Gompers, P., Kovner, A., Lerner, J., \& Scharfstein, D. (2010). Performance persistence in entrepreneurship. Journal of Financial Economics, 96, 18-32. https://doi.org/10. 1016/j.jineco.2009.11.001

Gottschalk, S., Greene, F. J., \& Müller, B. (2017). The impact of habitual entrepreneurial experience on new firm closure outcomes. Small Business Economics, 48(2), 303-321. https://doi.org/10.1007/s11187-016-9780-3

Gruber, M., MacMillan, I. C., \& Thompson, J. D. (2012). From Minds to Markets: How human capital endowments shape market opportunity identification of technology start-ups. Journal of Management, 38(5), 1421-1449. https://doi. org/10.1177/0149206310386228

Headd, B. (2003). Redefining business success: Distinguishing between closure and failure. Small Business Economics, 21, 51-61. https://doi.org/10.1023/A:10244 33630958

Hessels, J., Grilo, I., Thurik, R., \& van der Zwan, P. (2011). Entrepreneurial exit and entrepreneurial engagement. Journal of Evolutionary Economics, 21(3), 447-471. https://doi.org/10.1007/s00191-010-0190-4

Hoetker, G., \& Agarwal, R. (2007). Death hurts, but it isn't fatal: The post-exit diffusion of knowledge created by innovative companies. Academy of Management Journal, 50(2), 446467. https://doi.org/10.5465/amj.2007.24634858

Holmes, T. J., \& Schmitz, J. A. (1990). A theory of entrepreneurship and its application to the study of business transfers. Journal of Political Economy, 98(2), 265-294. https://doi.org/10.1086/261678

Hudson, R. L., \& McArthur, A. W. (1994). Contracting strategies in entrepreneurial and established firms. Entrepreneurship Theory and Practice, 18(4), 43-59. https://doi. org/10.1177/104225879401800304 
Jenkins, S. (2005). Survival Analysis. University of Essex, Colchester, UK.

Jovanovic, B. (1982). Selection and the evolution of industry. Econometrica, 50(3), 649-670. https://doi.org/10.2307/ 1912606

Knott, A. M., \& Posen, H. E. (2005). Is failure good? Strategic Management Journal, 26(7), 617-641. https://doi.org/10. 1002/smj.470

Lafontaine, F., \& Shaw, K. (2016). Serial entrepreneurship: Learning by doing? Journal of Labor Economics, 34(2), S217-S254. https://doi.org/10.1086/683820

Lin, Z. X., Picot, G., \& Compton, J. (2000). The entry and exit dynamics of self-employment in Canada. Small Business Economics, 15(2), 105-125. https://doi.org/10.1023/A: 1008150516764

Lucas, R. E. (1978). On the size distribution of business firms. The Bell Journal of Economics, 9(2), 508-523. https://doi. org/10.2307/3003596

Mata, J., \& Portugal, P. (1994). Life duration of new firms. The Journal of Industrial Economics, 42(3), 227-245. https:// doi.org/10.2307/2950567

McGrath, R. G. (1999). Falling forward: Real options reasoning and entrepreneurial failure. Academy of Management Review, 24(1), 13-30. https://doi.org/10.5465/amr.1999. 1580438

McGrath, R. G., \& MacMillan, I. C. (2000). The entrepreneurial mindset: Strategies for continuously creating opportunity in an age of uncertainty. Harvard Business School Press.

Metzger, G. (2006a). Afterlife - Who takes heart for restart?, ZEW Discussion Paper 06-038. Mannheim. https://doi. org/10.2139/ssrn.908212

Metzger, G. (2006b). 'Once bitten, Twice Shy? The performance of entrepreneurial re-starts', ZEW Discussion Paper 06-083. Mannheim. https://doi.org/10.2139/ssrn. 955756

Metzger, G. (2007). Personal experience: A most vicious and limited circle!? On the Role of Entrepreneurial Experience for Firm Survival, ZEW Discussion Paper 07-046. Mannheim. https://doi.org/10.2139/ssrn.1008244

Mincer, J. (1974). Schooling, Experience, and Earnings. National Bureau of Economic Research.

Minniti, M., \& Bygrave, W. (2001). A Dynamic Model of Entrepreneurial Learning. Entrepreneurship Theory and Practice, 25(3), 5-16. https://doi.org/10.1177/10422 5870102500301

Nielsen, K., \& Sarasvathy, S. D. (2016). A market for lemons in serial Entrepreneurship? Exploring Type I and Type II Errors in the Restart Decision Academy of Management Discoveries, 2(3), 247-271. https://doi.org/10.5465/amd. 2014.0108

Parker, S. C. (2013). Do serial entrepreneurs run successively better-performing businesses? Journal of Business Venturing, 28, 652-666. https://doi.org/10.1016/j.jbusvent.2012. 08.001

Plehn-Dujowich, J. (2010). A theory of serial entrepreneurship. Small Business Economics, 35, 377-398. https://doi.org/ 10.1007/s11187-008-9171-5

Politis, D. (2005). The process of entrepreneurial learning: A conceptual framework. Entrepreneurship Theory and Practice, 29(4), 399-424. https://doi.org/10.1111/j.15406520.2005.00091.x
Rocha, V., Carneiro, A., \& Varum, C. A. (2015). Serial entrepreneurship, learning by doing and self-selection. International Journal of Industrial Organization, 91-106,. https://doi.org/10.1016/j.ijindorg.2015.04.001

Ronstadt, R. (1988). The corridor principle. Journal of Business Venturing, 3(1), 31-40. https://doi.org/10.1016/08839026(88)90028-6

Sarasvathy, S. D. (2001). Causation and effectuation: Toward a theoretical shift from economic inevitability to entrepreneurial contingency. Academy of Management Review, 26(2), 243-263. https://doi.org/10.5465/amr.2001.43780 20

Starr, J.A., and W.D. Bygrave (1992), The second time around: The outcomes, assets, and liabilities of prior start-up experience, In: S. Birley \& I.C. MacMillan (Eds), International perspectives on entrepreneurship research 1991: Proceedings of the first annual global conference on entrepreneurship research (pp. 340-363).

Senge, P. M. (1990). The Fifth Discipline: The Art and Practice of the Learning Organization. Century Business.

Shepherd, D. A., Douglas, E. J., \& Shanley, M. (2000). New venture survival: Ignorance, external shocks, and risk reduction strategies. Journal of Business Venturing, 15(5/6), 393-410. https://doi.org/10.1016/S08839026(98)00032-9

Shepherd, D. A. (2003). Learning from business failure: Propositions of grief recovery for the self-employed. Academy of Management Review, 28(2), 318-328. https://doi.org/ 10.5465/amr.2003.9416377

Schutjens, V., and E. Stam (2006), Starting anew: Entrepreneurial intentions and realizations subsequent to business closure, Papers in Evolutionary Economic Geography \# 06.05, Utrecht University.

Sitkin, S.B. (1992), Learning through failure: The strategy of small losses. In: Shaw, B.M., Cummings, L.L. Eds., Research in Organisational Behaviour, 14, 231-266.

Smilor, R. W. (1997). Entrepreneurship: Reflections on a subversive activity. Journal of Business Venturing, 12(5), 341-346. https://doi.org/10.1016/S0883-9026(97) 00008-6

Spivack, A. J., McKelvie, A., \& Haynie, J. M. (2014). Habitual entrepreneurs: Possible cases of entrepreneurship addiction? Journal of Business Venturing, 29, 651-667. https:// doi.org/10.1016/j.jbusvent.2013.11.002

Stam, E., Audretsch, D., \& Meijaard, J. (2008). Renascent entrepreneurship. Journal of Evolutionary Economics, 18, 493-507. https://doi.org/10.1007/ s00191-008-0095-7

Sueyoshi, G. T. (1995). A class of binary response models for grouped duration data. Journal of Applied Econometrics, 10(4), 411-431. https://doi.org/10.1002/jae. 3950100406

Ucbasaran, D., G.A. Alsos, P. Westhead, and M. Wright (2008), Habitual entrepreneurs, foundation and trends in entrepreneurship, 4(4), 309-450. DOI: https://doi.org/10. $1561 / 0300000014$

Ucbasaran, D., Westhead, P., Wright, M., \& Flores, M. (2010). The nature of entrepreneurial experience, business failure and comparative optimism. Journal of Business Venturing, 25, 541-555. https://doi.org/10.1016/j.jbusvent.2009. 04.001 
van Praag, M. (2003). business survival and success of young small business owners. Small Business Economics, 21(1), 1-17. https://doi.org/10.1023/A:10244 53200297

Wagner, J. (2003). Taking a second chance: Entrepreneurial re-starters in Germany. Applied Economics Quarterly, 49(3), 255-272. https://doi.org/10. 1007/3-540-28361-7_8
Wennberg, K., Wiklund, J., DeTienne, D. R., \& Cardon, M. S. (2010). Reconceptualizing entrepreneurial exit: Divergent exit routes and their drivers. Journal of Business Venturing, 25, 361-375. https://doi.org/10.1016/j.jbusvent.2009.01.001

Publisher's Note Springer Nature remains neutral with regard to jurisdictional claims in published maps and institutional affiliations. 